\title{
New developments in cooling techniques for machining superalloys
}

\author{
Nowe osiągnięcia w technikach chłodzenia \\ przy obróbce superstopów
}

\begin{abstract}
The paper presents an update of the recent literature on advances in cooling techniques for machining of difficult to machine materials such as nickel and titanium-based alloys used in aero-engine and aerostructure applications. The review covers: cryogenic machining, minimum quantity lubrication, the combination of MQL and cryogenic cooling, and high-pressure lubricoolant supply. Examples of applications in industrial processes are also given.

KEYWORDS: cooling techniques, cryogenic machining, cryogenic cooling, minimum quantity lubrication, MQL, high-pressure lubricoolant supply, difficult to machine materials, nickel alloys, titanium-based alloys
\end{abstract}

W artykule przedstawiono najnowsze osiągnięcia w technikach chłodzenia przy obróbce materiałów trudnoobialnych, takich jak stopy niklu i stopy tytanu, stosowanych w silnikach i konstrukcjach lotniczych. Przegląd obejmuje: chłodzenie kriogeniczne i minimalne, połączenie tych technik, czyli kriogeniczne chłodzenie minimalne, oraz chłodzenie pod wysokim ciśnieniem. Przedstawiono również przykłady zastosowań przemysłowych.

SŁOWA KLUCZOWE: chłodzenie, chłodzenie kriogeniczne, chłodzenie minimalne, chłodzenie pod wysokim ciśnieniem, materiały trudnoobrabialne, superstopy, stopy niklu, stopy tytanu

\section{Wprowadzenie}

Superstopy, takie jak stopy tytanu i niklu, mają doskonałe właściwości mechaniczne i chemiczne w wysokiej temperaturze, dzięki czemu są szeroko stosowane w przemyśle lotniczym, oceanicznym i chemicznym. Jednak ze względu na te właściwości są one trudne w obróbce. Zmienność grubości wiórów, wysokie naprężenia cieplne i obciążenia ciśnieniowe, sprężynowanie oraz naprężenia szczątkowe są odpowiedzialne za większe zużycie narzędzi i gorszą jakość warstwy wierzchniej.

Obniżenie temperatury w strefie skrawania jest koniecznym warunkiem, aby uzyskać akceptowalną trwałość narzędzia skrawającego i jakość warstwy wierzchniej. Konwencjonalne chłodzenie zalewowe (obfite) jest szkodliwe dla zdrowia i dla środowiska, dlatego potrzebne jest wprowadzanie nowych, bardziej ekologicznych technik smarowania i chłodzenia, zwłaszcza w obróbce trudno skrawalnych materiałów. Chłodzenie kriogeniczne jest skuteczną metodą zwiększenia obrabialności i odprowadzenia ciepła w strefie skrawania, ponieważ wpływa na właściwości narzędzia skrawającego i obrabianego przedmiotu dzięki użyciu bardzo zimnego medium, takiego jak ciekły azot (liquid nitrogen - $\mathrm{LN}_{2}$ ) lub ciekły dwutlenek węgla (liquid carbon dioxide - $\mathrm{LCO}_{2}$ ). Innym przyjaznym dla środowiska rozwiązaniem jest smarowanie minimalne (minimum quantity lubrication - MQL), w którym w strefie skrawania rozpylana jest optymalna ilość chłodziwa. Bardzo obiecujące są nanociecze - dyspersja niemetalicznych lub metalicznych nanododatków o wielkości poniżej 100 nm w cieczy bazowej. Mają one doskonałe właściwości chłodzące ze względu na zaawansowane możliwości ekstrakcji wytworzonego ciepła.

Zagadnienia te są przedmiotem zainteresowania światowej nauki i poświęcono im wiele świetnych przeglądów literatury, np. [1-6]. Tu zostaną omówione jedynie najnowsze osiągnięcia w technikach chłodzenia przy obróbce superstopów - z lat 2018-2020.

\section{Chłodzenie kriogeniczne}

Największe wyzwania podczas obróbki trudnoobrabialnych stopów używanych w krytycznych zastosowaniach lotniczych to zwiększenie trwałości narzędzia i poprawa jakości warstwy wierzchniej elementu. Obróbka stopów tytanu i niklu jest trudna ze względu na ich słabą przewodność cieplną. Wybór chłodziwa i warunków obróbki ma kluczowe znaczenie dla zwiększenia wydajności. W przypadku smarowania konwencjonalnego (obfitego, zalewowego) przy większej wydajności obróbki chłodziwo nie dociera do strefy skrawania i dochodzi do zanieczyszczenia środowiska [7]. Takie chłodzenie jest nieefektywne, ponieważ zależy głównie od różnicy temperatur. Podczas stygnięcia emulsja pozostaje w stanie ciekłym, przez co dłużej ma kontakt z gorącą strefą skrawania lub powierzchnią obrabianego przedmiotu [8, 9]. Do obniżenia wysokiej temperatury w strefie skrawania i podwyższenia wydajności obróbki niezbędne jest lepsze odprowadzanie ciepła.

W tym kontekście obiecującym podejściem jest chłodzenie kriogeniczne za pomocą ciekłego azotu $\mathrm{LN}_{2}$ lub ciekłego dwutlenku węgla $\mathrm{LCO}_{2}$. Mechanizm odprowadzania ciepła $\mathrm{LN}_{2}$ i $\mathrm{LCO}_{2}$ zależy głównie od absorpcji ciepła w wyniku przemiany fazowej medium. Ponadto

\footnotetext{
* Prof. dr hab. inż. Krzysztof Jemielniak, krzysztof.jemielniak@pw.edu.pl, https://orcid.org/0000-0002-7156-7878 - Wydział Inżynierii Produkcji, Politechnika Warszawska, Warszawa, Polska
} 


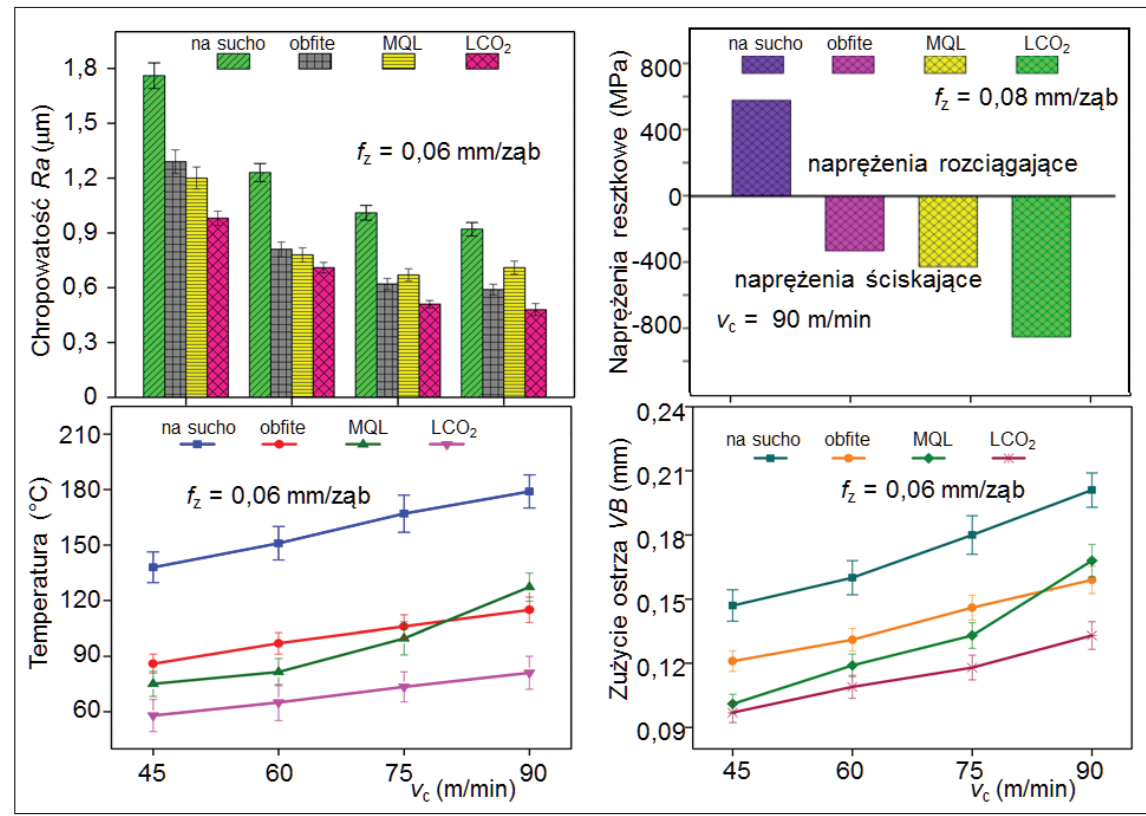

Fig. 1. Results of $\mathrm{LCO}_{2}$ cooling application in milling of Nimonic 80A [7]

Rys. 1. Wyniki zastosowania chłodzenia $\mathrm{LCO}_{2}$ podczas frezowania Nimonic 80A [7]
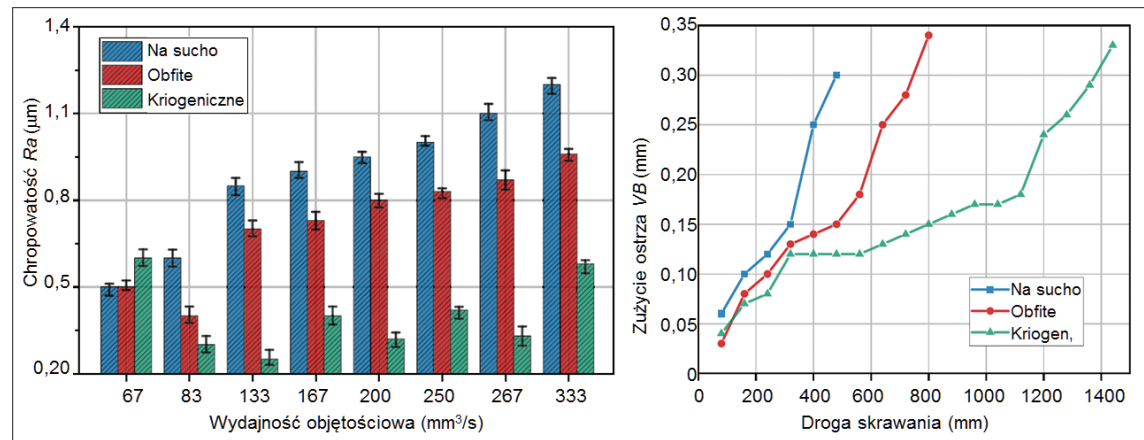

Fig. 2. $R a$ variation at different material removal rates values and flank wear behavior for turning of Ti6Al4V under altered cutting conditions [13]

Rys. 2. Zmienność Ra przy różnych wydajnościach obróbki i zużycia powierzchni przyłożenia przy toczeniu Ti6Al4V w różnych warunkach chłodzenia [13]

chłodzenie kriogeniczne budzi ostatnio zainteresowanie jako czysta i ekonomiczna technika [10].

Przegląd głównych procesów obróbki kriogenicznej, podsumowujący najnowocześniejsze rozwiązania i znaczące zmiany, które zaszły w ciągu ostatnich kilku dekad, można znaleźć w [11]. Tutaj prezentowane są tylko najnowsze pomysły i wyniki badań.

Chłodzenie kriogeniczne ma duży wpływ na jakość obrabianej powierzchni i ogranicza zużycie narzędzia, ponieważ obniża temperaturę $\mathrm{w}$ strefie skrawania (patrz np. rys. 1 i 2). Te znane od dawna efekty znajdują potwierdzenie również w najnowszej literaturze $[7,12,13]$.

Jednak niektóre badania wykazały, że podczas gdy konwencjonalne smarowanie i chłodzenie $\mathrm{LCO}_{2}$ pozwala uzyskać podobne: czas obróbki, zużycie narzędzia i jakość obrobionej powierzchni, zastosowanie $\mathrm{LN}_{2}$ przy toczeniu Inconelu 718 niekorzystnie wpływa na trwałość ostrza i jakość powierzchni. $\mathrm{Z}$ drugiej strony, w porównaniu $\mathrm{z}$ konwencjonalnym smarowaniem, oba rodzaje chłodzenia kriogenicznego zapewniają lepsze profile naprężeń szczątkowych wzdłuż obrabianych powierzchni [14].

Nadmierne chłodzenie przedmiotu obrabianego przez $\mathrm{LN}_{2}$ może powodować kruchość i utwardzenie materiału, a w konsekwencji - większe ścieranie, mimo zmniejszenia mechanizmów zużycia aktywowanych termicznie, co ogranicza wystąpienie zużycia kraterowego. Jednak gazowy $\mathrm{N}_{2}$ schłodzony do temperatury $-100^{\circ} \mathrm{C} \div-150^{\circ} \mathrm{C}$ pozwala też na redukcję ciepła powstającego podczas skrawania, co sprzyja ograniczeniu zużycia kraterowego, ale bez modyfikowania początkowych właściwości materiału, oraz ograniczeniu zużycia powierzchni przyłożenia. Zastosowanie schłodzonego gazowego $\mathrm{N}_{2}$ jest więc najlepszą strategią toczenia półwykończeniowego Ti6Al4V, ponieważ minimalizuje wady i zmiany mikrostrukturalne powierzchni, zapewniając jednocześnie znaczny stan naprężeń szczątkowych przy ściskaniu, który może poprawić wytrzymałość zmęczeniową części [15, 16] (rys. 3).

Również zastosowanie glikolu etylowego (GE) schłodzonego do $-30^{\circ} \mathrm{C}$ do toczenia zgrubnego Ti6Al4V skutkowało mniejszym zużyciem narzędzia i bardziej korzystnym formowaniem wiórów $\mathrm{w}$ porównaniu
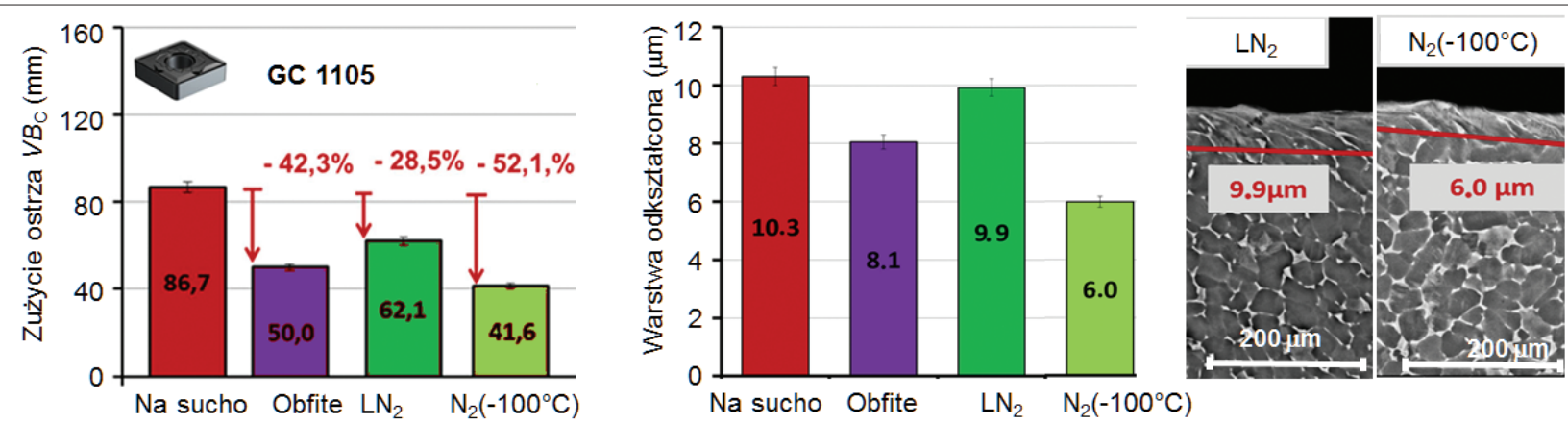

Fig. 3. Tool flank wear and thickness of the machining-altered layer as a function of the adopted cooling strategies during semi-finishing turning of the Ti6Al4V $[15,16]$

Rys. 3. Zużycie powierzchni przyłożenia narzędzia i grubość warstwy zdeformowanej przez obróbkę w funkcji przyjętych strategii chłodzenia podczas toczenia półwykończeniowego Ti6Al4V [15, 16] 


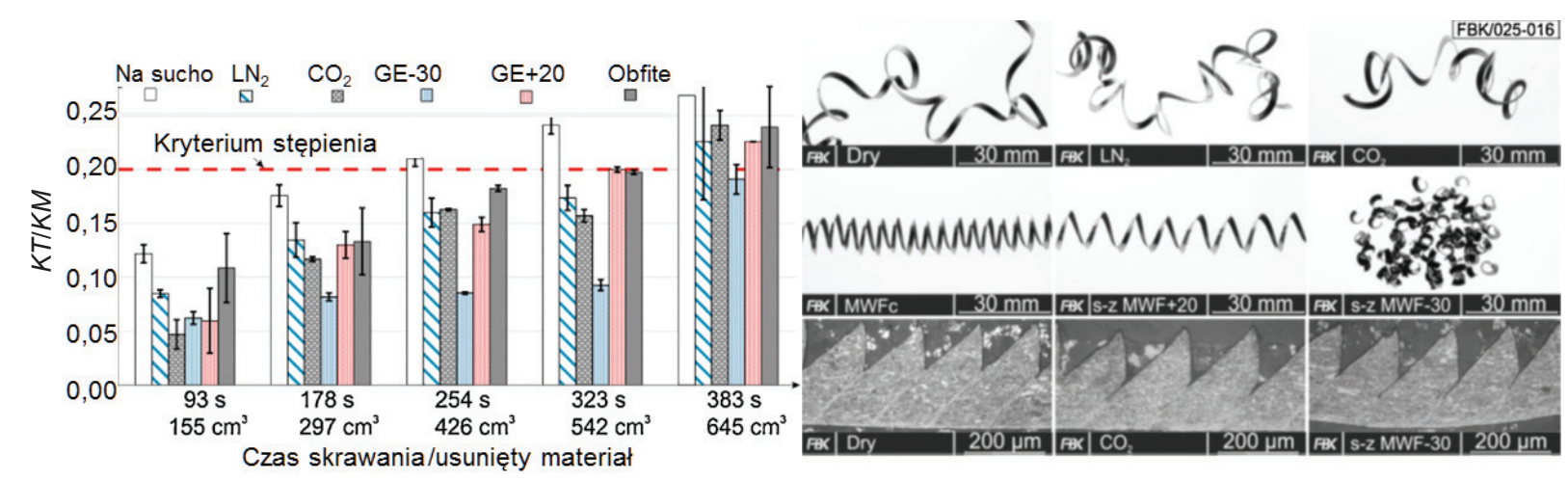

Fig. 4. Crater ratio as a function of cutting time/travel path and generated chips and etched longitudinal cut during rough turning of Ti6Al4V [17]

Rys. 4. Stosunek głębokości krateru do odległości jego środka od krawędzi skrawającej (KT/KM) w funkcji czasu skrawania i usuniętego materiału oraz generowanych wiórów podczas toczenia zgrubnego Ti6Al4V przy stosowaniu różnych chłodziw [17]

z obróbką na sucho, chłodzeniem $\mathrm{LN}_{2}, \mathrm{CO}_{2}$, GE w temperaturze pokojowej i obfitym chłodzeniem estrem $8 \%$ [17].

Innym sposobem na utrzymanie normalnej temperatury obrabianego przedmiotu z Ti6Al4V, a tym samym zapobieżenie jego utwardzaniu, jest pośrednie chłodzenie kriogeniczne, w którym ciekły azot jest dostarczany tylko do schłodzenia narzędzia, bez narażania go na kontakt z obrabianym przedmiotem.

\section{Smarowanie minimalne - MQL}

Chłodzenie zalewowe jest typową przemysłową strategią obniżania wysokich temperatur powstających podczas obróbki trudno skrawalnych materiałów. Powoduje ono jednak wiele zagrożeń środowiskowych i zdrowotnych, stąd konieczność poszukiwania innych rozwiązań. Jednym z nich jest smarowanie minimalne (minimum quantity lubrication - MQL). Obszerny przegląd literatury dotyczącej wykorzystania techniki MQL podczas obróbki materiałów trudnoobrabialnych można znaleźć w [3]. Wyniki dla chłodzenia MQL i zalewowego pod względem szybkości zużycia i trwałości narzędzia są podobne. Większość badań pokazuje, że MQL znacznie poprawia wydajność obróbki w porównaniu z obróbką na sucho. Można więc stwierdzić, że technika MQL jest skuteczną alternatywą dla konwencjonalnych sposobów chłodzenia.

Przykładowo: ocena porównawcza natężenia przepływu modyfikowanego, wysokooleinowego oleju sojowego podczas frezowania czołowego Inconelu 718, z użyciem niedrogich płytek z węglika powlekanego i konwencjonalnego chłodzenia zalewowego, pokazuje, że natężenie przepływu oleju w MQL ma duży wpływ na trwałość narzędzia i wynikową siłę skrawania, a optimum osiąga przy $70 \mathrm{ml} / \mathrm{h}$. Zwiększenie szybkości przepływu MQL zmniejsza chropowatość powierzchni i zużycie narzędzia, tworząc wystarczający cienki film olejowy, ale jednocześnie prowadzi do wzrostu powinowactwa z wiórami i powstawania dużych narostów (rys. 5) [19].

Potencjał rozpraszania ciepła przy stosowaniu MQL jest jednak znacznie niższy niż w przypadku chłodzenia obfitego. Jedną z sugerowanych technik dalszej poprawy wydajności MQL, zwłaszcza podczas obrób-

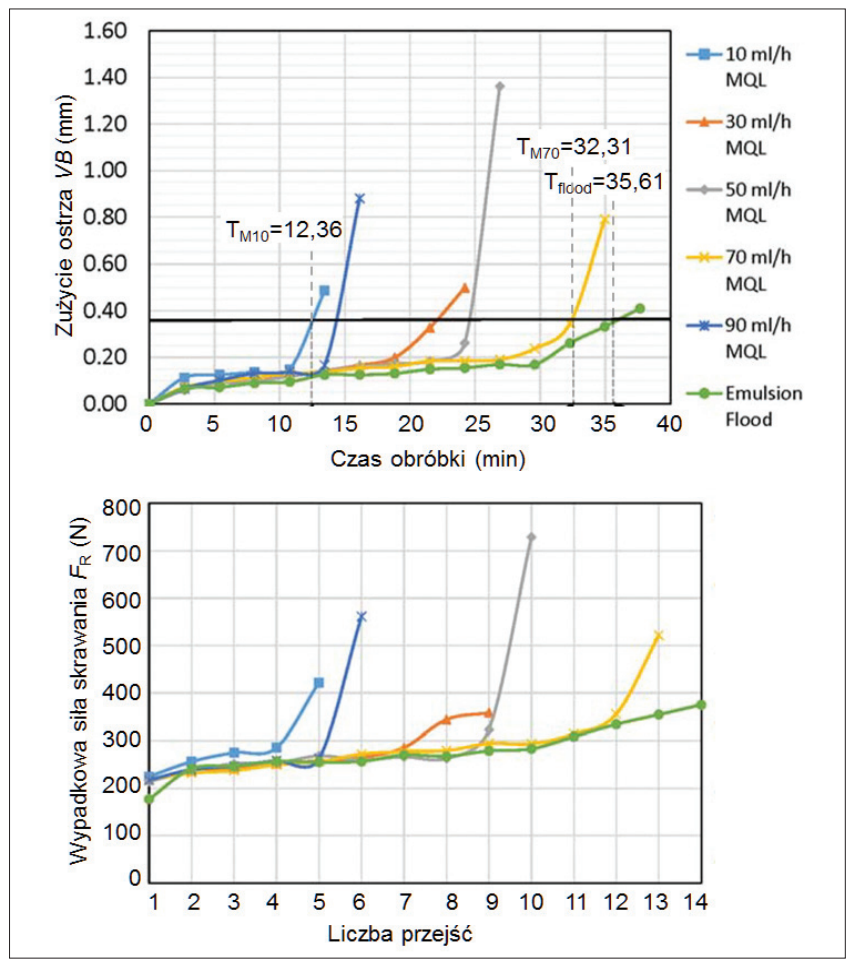

Fig. 5. Maximum flank wear vs. machining time and resultant cutting force vs. machining pass from the $1^{\text {st }}$ to final pass under cooling-lubrication strategies [19]

Rys. 5. Maksymalne zużycie powierzchni przyłożenia w zależności od czasu obróbki i wypadkowej siły skrawania w funkcji numeru przejścia przy różnych sposobach chłodzenia [19]

ki trudno skrawalnych materiałów, jest zastosowanie płynów MQL-nano. Nanopłyn to dyspersja metalicznych/niemetalicznych nanocząstek lub nanowłókien o określonej wielkości, mniejszych niż $100 \mathrm{~nm}$, w podstawowym płynie obróbkowym. Nanocząstki mogą drastycznie zwiększyć zdolność przenoszenia ciepła przez płyny do obróbki metalu [20].

Na rys. 6 przedstawiono porównanie wyników frezowania Ti6Al4V uzyskanych po zastosowaniu jako chłodziwa MQL oleju bawełnianego modyfikowanego sześcioma różnymi nanocząstkami: $\mathrm{Al}_{2} \mathrm{O}_{3}, \mathrm{MoS}_{2}, \mathrm{SiO}_{2}$, nanorurkami węglowymi (carbon nanotubes - CNT), $\mathrm{SiC}$ i grafitem, w stosunku masowym 1,5\%. Najniższą siłę skrawania w kierunku $X$ uzyskano dla $\mathrm{Al}_{2} \mathrm{O}_{3}$, a następnie dla CNT. Efekt ten osłabia wytwarzanie ciepła, a tym samym zmniejsza temperaturę w strefie 


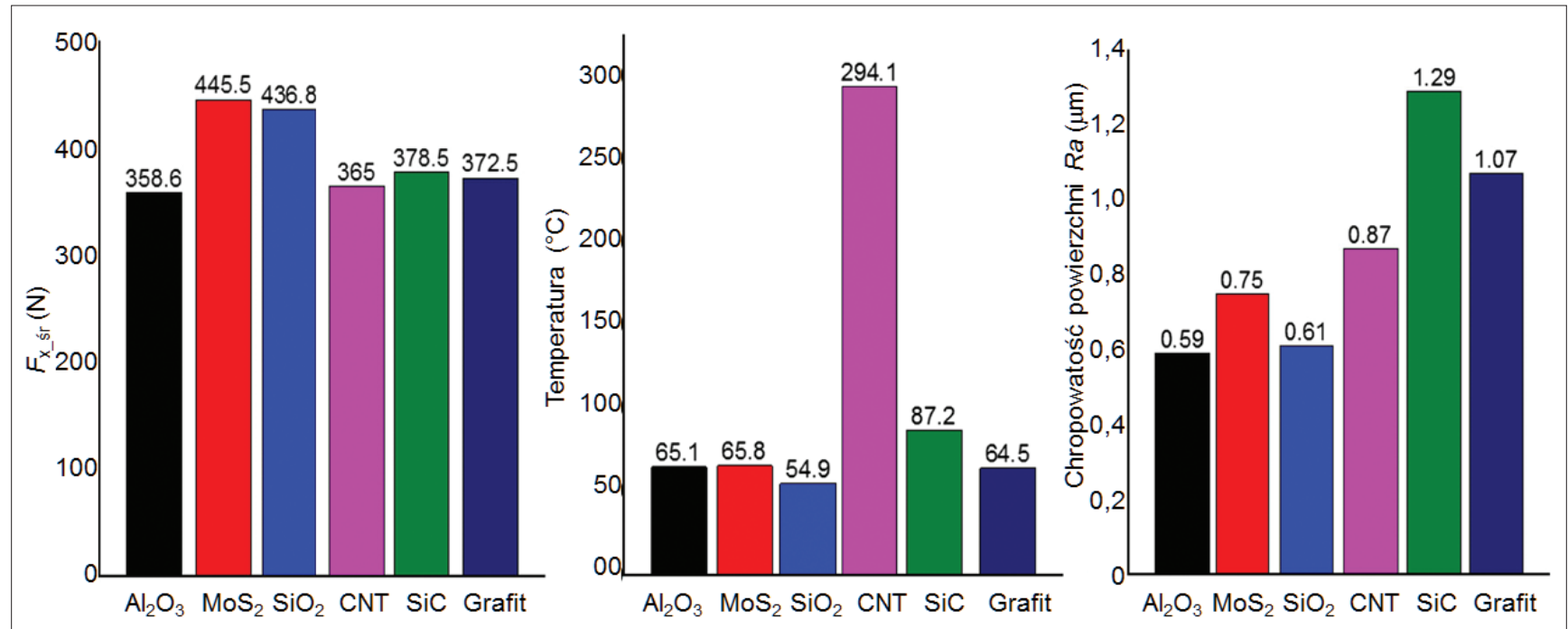

Fig. 6. Comparison of mean values of milling force, the peak temperature and surface roughness values of workpieces under MQL with different nanoparticles under milling of Ti6Al4V [20]

Rys. 6. Porównanie średnich wartości siły skrawania, szczytowej temperatury i chropowatości powierzchni przedmiotów z Ti6Al4V obrabianych z MQL wzbogaconym różnymi nanocząstkami [20]

skrawania. Na rys. 6 widać drastyczny wzrost temperatury podczas frezowania nanocieczą CNT pomimo niewielkiej siły skrawania. Można to przypisać agregacji CNT, która zmniejsza zdolność rozpraszania ciepła. Temperatura przedmiotu obrabianego podczas frezowania z innymi nanocieczami wynosiła poniżej $100^{\circ} \mathrm{C}$, co wskazuje na wysoką przewodność cieplną i zdolność chłodzenia. Duża siła frezowania i niska temperatura przedmiotu obrabianego podczas frezowania z nanocieczą $\mathrm{SiO}_{2}$ wskazują, że nanocząstki $\mathrm{SiO}_{2}$ miały największą zdolność chłodzenia spośród badanych. Najniższą wartość $R a$ uzyskano dla nanocieczy z $\mathrm{Al}_{2} \mathrm{O}_{3}$ (o $66,7 \%$ niższą od uzyskanej z czystym olejem bawełnianym), a następnie dla $\mathrm{SiO}_{2}$. Ponieważ nanocząstki $\mathrm{Al}_{2} \mathrm{O}_{3} \mathrm{i} \mathrm{SiO}_{2}$ wykazały najlepszą wydajność chłodzenia, są one bardzo odpowiednimi dodatkami do MQL.

Zastosowanie nanocieczy $\mathrm{z}$ wielościennymi nanorurkami węglowymi i nanocząstkami $\mathrm{Al}_{2} \mathrm{O}_{3}$ podczas toczenia Inconelu 718 daje lepsze wyniki w porówna-

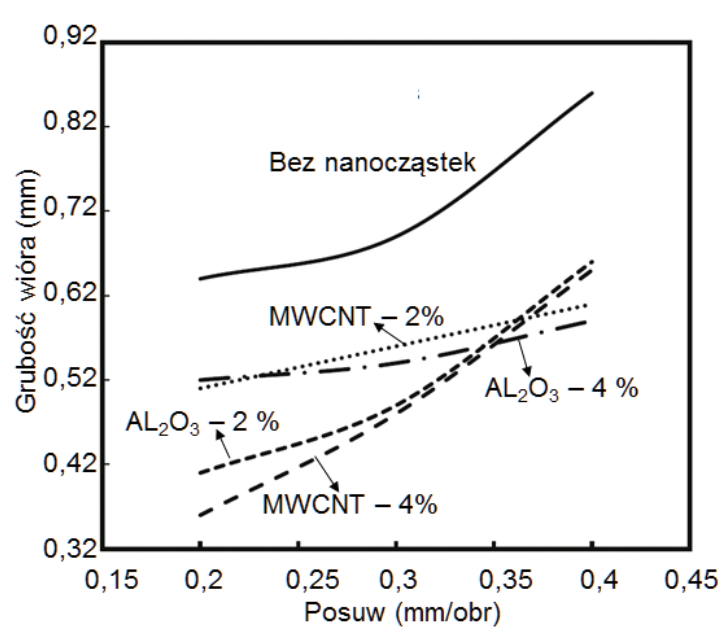

Fig. 7. Effect of feed on chip thickness when machining Inconel 718 with and without nanofluid [21]

Rys. 7. Wpływ posuwu na grubość wiórów podczas obróbki Inconelu 718 z nanocieczą i bez niej [21] niu z MQL bez nanododatków. W przypadku stosowania nanocieczy zaobserwowano istotne zmiany sposobów zużycia narzędzi oraz obniżenie intensywności tego zużycia. Stwierdzono także mniejszą grubość wiórów, co przypisuje się zwiększeniu kąta ścinania (rys. 7). W konsekwencji generowane są mniejsze siły skrawania oraz wzrasta efektywność odprowadzania ciepła, co zapobiega tendencji do zgrzewania wiórów występującej podczas skrawania bez nanododatków. Ponadto dodatek rozproszonych wielościennych nanorurek węglowych do oleju roślinnego podczas toczenia Ti6Al4V zmniejsza pobór mocy i zużycie powierzchni przyłożenia [21].

Dodatek $\mathrm{MoS}_{2}$ jako stałego środka smarnego do oleju roślinnego stosowanego do MQL podczas toczenia Inconelu 718 ceramicznymi narzędziami skrawającymi wzmocnionymi wiskerami znacznie poprawił trwałość ostrza, jakość warstwy wierzchniej i chropowatość powierzchni. Lepsze wyniki uzyskano z zastosowaniem bazowego oleju roślinnego $\mathrm{z}$ dodatkiem $20 \%$ grafitu; pod względem siły skrawania smary dawały najmniejsze wartości (rys. 8) [22].

Zastosowanie $\mathrm{MoS}_{2}$ o wielkości cząstek $10 \div 15 \mu \mathrm{m}$ i proszku grafitowego o wielkości cząstek $30 \div 45 \mu \mathrm{m}$ do agresywnej obróbki Inconelu 718 z MQL zmniejszyło o $50 \div 65 \%$ zużycie powierzchni przyłożenia i o $39-51 \%$ chropowatość powierzchni w porównaniu z obróbką na sucho. Wynikało to z oddziaływania smaru stałego na styku narzędzie-wiór, które ograniczało powstawanie karbu i pękanie krawędzi narzędzia (rys. 9) [23].

Olej roślinny w MQL wzbogacony cząsteczkami PTFE (teflonu) oraz wodny roztwór z dodatkiem grafitu $w$ różnych proporcjach, stosowane do toczenia Ti6Al4V, obniżyły zarówno zużycie ostrza, jak i odkształcenia warstwy wierzchniej (rys. 10) [24].

Grafen to kolejny dodatek używany ostatnio w nanocieczach obróbkowych. Podczas stosowania MQL na bazie oleju roślinnego z rozproszonymi nanocząstkami grafenu do frezowania TC4 siła skrawania znacznie spada. Jest to prawdopodobnie spowodowane 

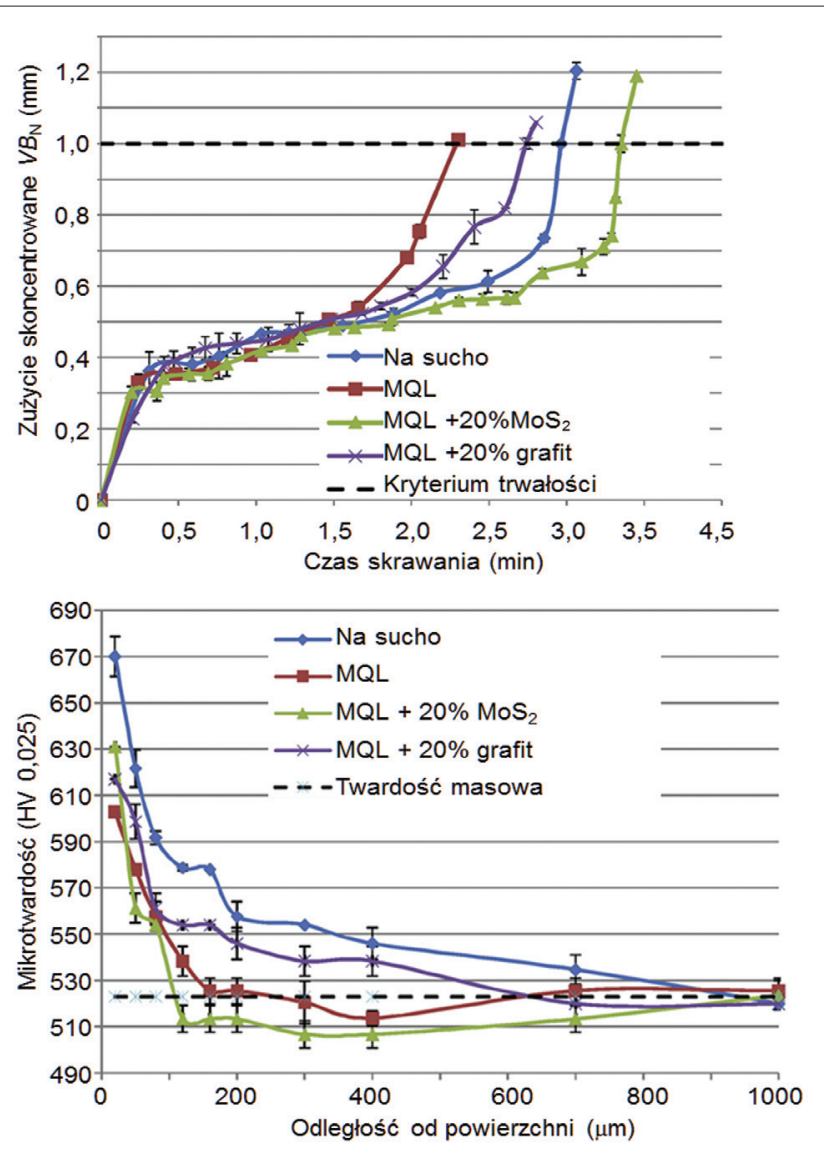

Fig. 8. Notch wear vs. time for machining Inconel 718 and workpiece subsurface microhardness under various lubri-cooling conditions for worn edge $\left(v_{\mathrm{c}}=250 \mathrm{~m} / \mathrm{min}, f=0.1 \mathrm{~mm}, a_{\mathrm{p}}=0.5 \mathrm{~mm}\right)$ [22]

Rys. 8. Zużycie skoncentrowane (karb) w funkcji czasu skrawania i mikrotwardości pod powierzchnią obrabiana po obróbce Inconelu 718 stępionym ostrzem, $w$ różnych warunkach chłodzenia $\left(v_{\mathrm{c}}=250\right.$ $\left.\mathrm{m} / \mathrm{min}, f=0,1 \mathrm{~mm} a_{\mathrm{p}}=0,5 \mathrm{~mm}\right)[22]$

wpływem dodatku grafenu na zwiększenie odporności na tarcie i nośności filmu olejowego utworzonego w strefie skrawania. Intensywność drgań podczas frezowania jest również znacznie mniejsza - dodatek grafenu wzmacnia efekt tłumienia filmu olejowego. Temperatura jest znacznie obniżona, ponieważ grafen zwiększa wydajność chłodzenia przez film olejowy. Skutkuje to mniejszym zużyciem narzędzia i większą jego trwałością przy chłodzeniu MQL z grafenem

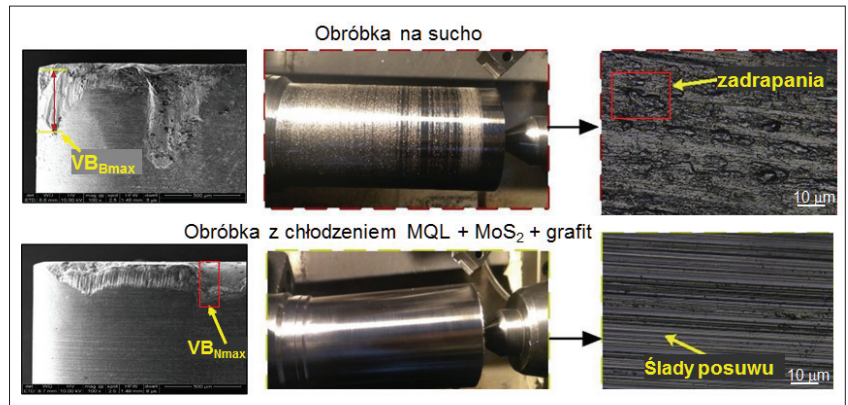

Fig. 9. SEM view of flank face surface and roughness under dry and MQL cooling at $f=0.1 \mathrm{~mm} / \mathrm{rev}, v_{\mathrm{c}}=350 \mathrm{~m} / \mathrm{min}, a_{\mathrm{p}}=0.3 \mathrm{~mm}$ [23] Rys. 9. Widok SEM powierzchni przyłożenia i chropowatości przy chłodzeniu na sucho i MQL przy: $f=0,1 \mathrm{~mm} / \mathrm{obr}, v_{\mathrm{c}}=350 \mathrm{~m} / \mathrm{min}$, $a_{\mathrm{p}}=0,3 \mathrm{~mm}[23]$

w porównaniu z czterema innymi warunkami chłodzenia/smarowania. Polepsza również jakość warstwy wierzchniej. Ogólnie więc dodatek grafenu korzystnie wpływa na parametry obróbki skrawaniem, gdyż poprawia charakterystykę chłodzenia i smarowania cieczy obróbkowej na bazie oleju roślinnego [25].

Wyniki zastosowania nanopłytek grafenu w dwóch rozmiarach $(5 \mu \mathrm{m}$ i $15 \mu \mathrm{m})$ jako dodatków do oleju roślinnego podczas toczenia Inconelu 718 wykazały, że im mniejsze nanopłytki, tym lepsza jakość powierzchni i znaczniejsze deformacje plastyczne warstwy wierzchniej $\mathrm{w}$ porównaniu $\mathrm{z}$ chłodzeniem zalewowym [26]. Podobne wyniki przedstawiono w [27], gdzie wprowadzenie nanopłytek grafenu o wielkości $5 \mu \mathrm{m}$ do oleju roślinnego przyczyniło się do zwiększenia pojemności cieplnej nanocieczy, bez zwiększania jej lepkości, i uzyskania najlepszej chropowatości powierzchni. Przeciwne wyniki uzyskano po dodaniu cząstek o wielkości $15 \mu \mathrm{m}$, które nie poprawiły jakości powierzchni w porównaniu z czystym MQL i chłodzeniem zalewowym (rys.11). To dowodzi, że skuteczność nanocząstek jako dodatków do płynów obróbkowych zależy od ich wielkości, co z kolei wpływa na ich właściwości termofizyczne.

Zastosowanie nanocieczy z tlenkiem grafenu (GO) do toczenia Ti6Al4V skutkuje uzyskaniem znacznie mniejszej chropowatości powierzchni, mniejszymi zarysowaniami i odkształceniami plastycznymi oraz niższą temperaturą skrawania w porównaniu z użyciem
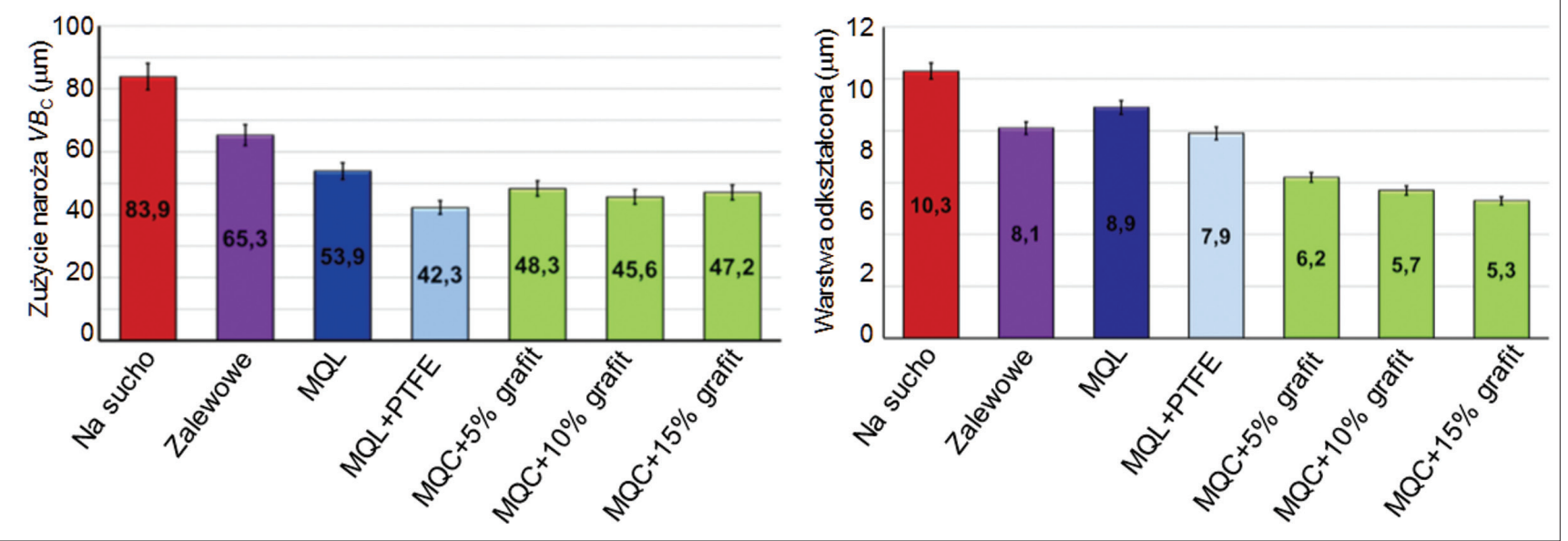

Fig. 10. Notch wear $V B_{C}$ and thickness of the deformed layer as a function of the adopted lubrication/cooling strategies [24] Rys. 10. Zużycie naroża $V B_{C}$ i grubość zdeformowanej warstwy w zależności od przyjętych strategii smarowania/chłodzenia [24] 


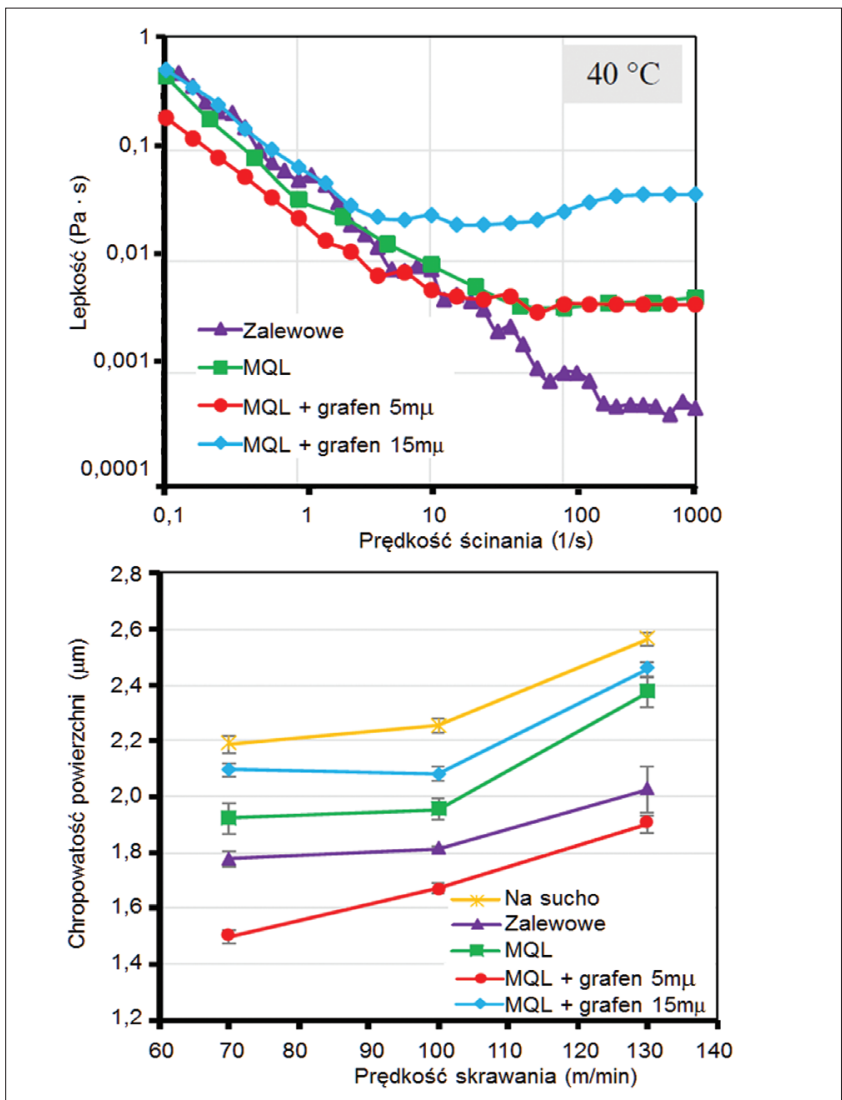

Fig. 11. Dynamic viscosity of the investigated cutting fluids at $40^{\circ} \mathrm{C}$ as a function of the shear rate and surface roughness as a function of the cutting speed and lubricating-cooling conditions [27] Rys. 11. Lepkość dynamiczna badanych cieczy obróbkowych w temperaturze $40^{\circ} \mathrm{C}$ w funkcji szybkości ścinania i chropowatość powierzchni w funkcji prędkości skrawania oraz warunków smarująco-chłodzących [27]
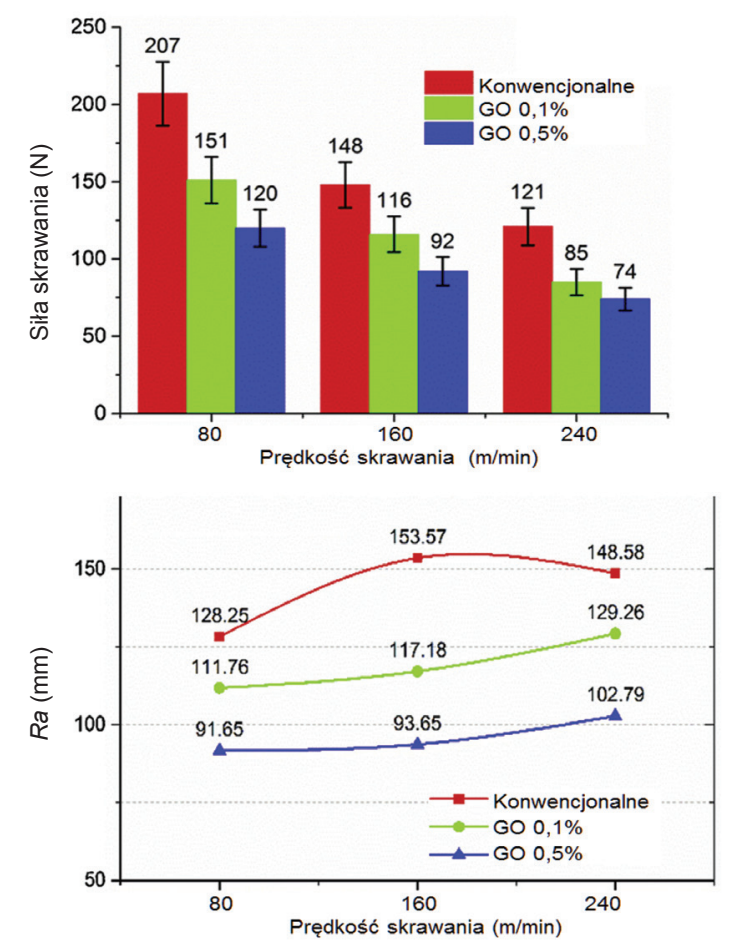

Fig. 12. Cutting forces and roughness of machined surface under 1-bar coolant pressure for conventional coolant and MQL with graphene oxide nanosheets of $0.1 \%$ and $0.5 \%$ weight percentages [29] Rys. 12. Siły skrawania i chropowatość obrabianej powierzchni dla konwencjonalnego chłodziwa pod ciśnieniem 1 bar i MQL z nanopłytkami tlenku grafenu 0,1\% i 0,5\% wagowo [29]

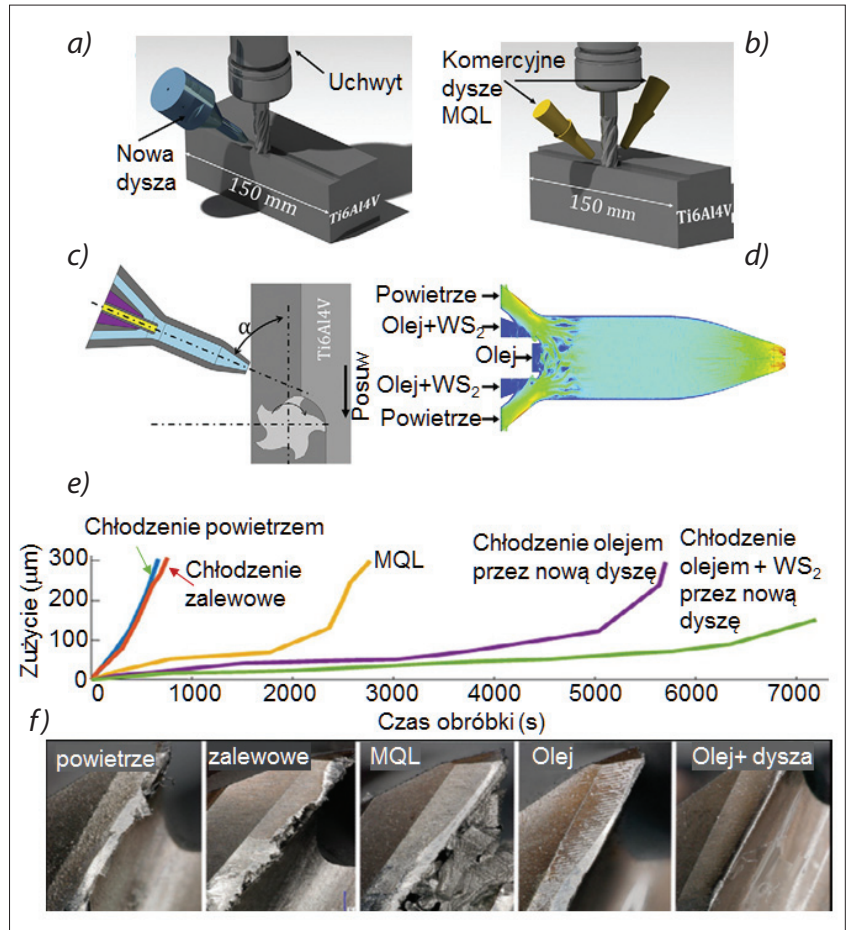

Fig. 13. Experimental setup, with: $a$ ) the new and $b$ ) commercial nozzles; $c$ ) the nozzle orientation, $d$ ) detail of the new nozzle, e) tool wear at a cutting speed $150 \mathrm{~m} / \mathrm{min}$ and $f$ ) end of test tool wear images after machining with various cooling: air, flood, commercial MQL, newly designed MQL nozzle spraying both rapeseed oil alone and a $\mathrm{WS}_{2}$-rapeseed oil suspension [30]

Rys. 13. Układ doświadczalny z: $a$ ) nowymi i $b$ ) dostępnymi na rynku dyszami; c) orientacja dyszy; d) szczegóły nowej dyszy; e) zużycie narzędzia przy prędkości skrawania $150 \mathrm{~m} / \mathrm{min}$; f) zdjęcia ostrzy na końcu testów po obróbce z różnymi rodzajami chłodzenia: powietrzem, zalewowym, komercyjnym MQL, a także nowo zaprojektowaną dyszą MQL rozpylającą sam olej rzepakowy oraz zawiesinę WS w oleju rzepakowym [30]

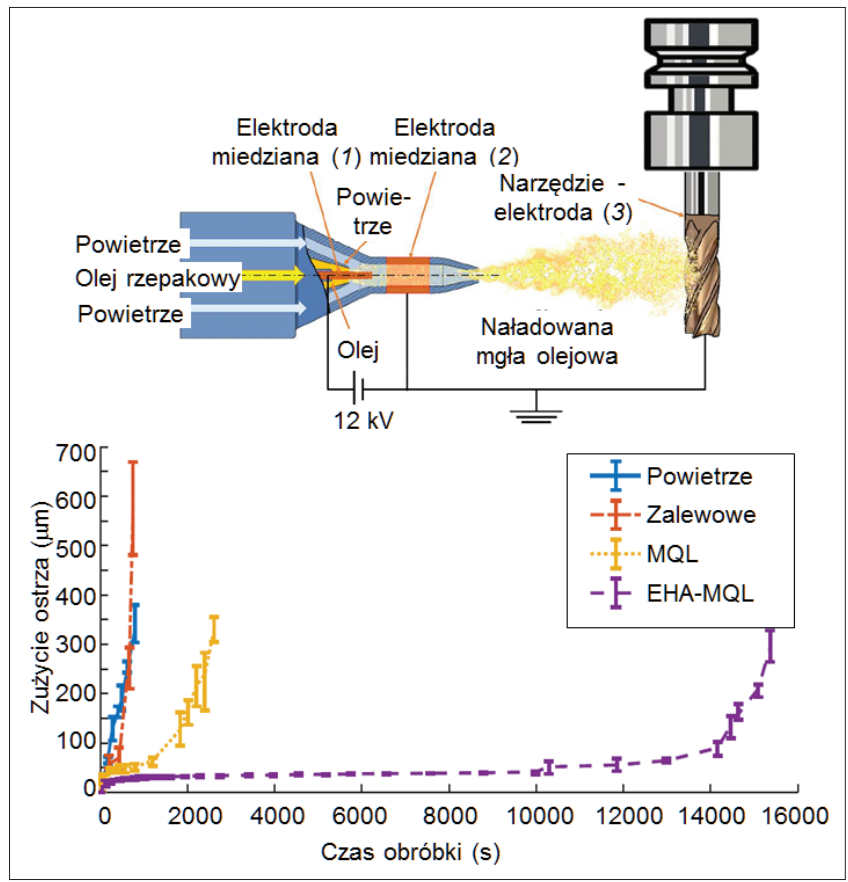

Fig. 14. Schematic of Electrohydrodynamic Atomization Minimum Quantity Lubrication (EHDA-MQL) nozzle and machining setup and tool-wear against machining time for various cooling-lubrication systems [31]

Rys. 14. Schemat atomizacji elektrohydrodynamicznej z minimalną ilością smarowania (EHA-MQL) - dysza i ustawienie obróbki oraz zużycie narzędzia w funkcji czasu obróbki dla różnych układów chłodząco-smarujących [31] 
konwencjonalnego chłodziwa [28]. Główna siła skrawania i chropowatość powierzchni maleją wraz ze wzrostem stężenia nanopłytek tlenku grafenu w płynie chłodzącym (rys. 12) [29].

Innym sposobem na poprawę efektywności MQL w obróbce materiałów lotniczych jest wprowadzanie innowacyjnego sposobu podawania medium. Może to być nowa dysza tłocząca MQL, która miesza dwa płyny $\mathrm{w}$ jeden strumień podczas skrawania Ti6Al4V z dużą prędkością [30]. Zawiesinę dwusiarczku wolframu $\left(\mathrm{WS}_{2}\right) \mathrm{w}$ oleju roślinnym miesza się w dyszy i dostarcza za pomocą sprężonego powietrza jako czynnik chłodząco-smarujący (rys. $13 a-d$ ). Przy optymalnym ustawieniu nowy system osiąga chłodzące odbieranie ciepła blisko $700 \mathrm{~W} / \mathrm{m}^{2} \mathrm{~K}$ oraz wzrost trwałości narzędzia o ok. 1,5 raza w porównaniu z kolejnym najlepszym systemem dostarczania MQL i od 3 do 11 razy w porównaniu z chłodzeniem powietrzem lub zalewowym (rys. $13 e-f$ ).

Zastosowanie atomizacji elektrohydrodynamicznej (electrohydrodynamic atomization - EHA) i układu trójelektrodowego do generowania kropelek smaru w obróbce Ti6Al4V wydłużyło żywotność narzędzia 6 i 22 razy w porównaniu z odpowiednio MQL i chło- dzeniem zalewowym (rys. 14). Poprawę wydajności przypisuje się zwiększonemu odprowadzaniu ciepła z powodu drobnych kropelek generowanych przez EHA, co skutkuje zmniejszeniem tempa wzrostu zużycia narzędzi [31].

\section{Chłodzenie kriogeniczne MQL - krio-MQL}

Z przeglądu literatury wynika, że chociaż chłodzenie kriogeniczne może zwiększyć skrawalność materiałów trudnoobrabialnych, jego wadą jest brak smarowania w strefie skrawania. Niedawno stwierdzono, że połączenie obróbki kriogenicznej i MQL (krio-MQL) poprawia wydajność obróbki materiałów lotniczych. Ta strategia chłodzenia/smarowania wykorzystuje fakt, że system dysz MQL rozpyla olej bezpośrednio na strefę skrawania, zapewniając smarowanie, które jest niezbędne do zmniejszenia tarcia między powierzchnią natarcia narzędzia a wiórem oraz między powierzchnią przyłożenia a obrabianym przedmiotem. Dysze kriogeniczne są skierowane głównie w stronę narzędzia skrawającego w celu obniżenia jego temperatury poniżej temperatury mięknięcia materiału narzędzia [32].

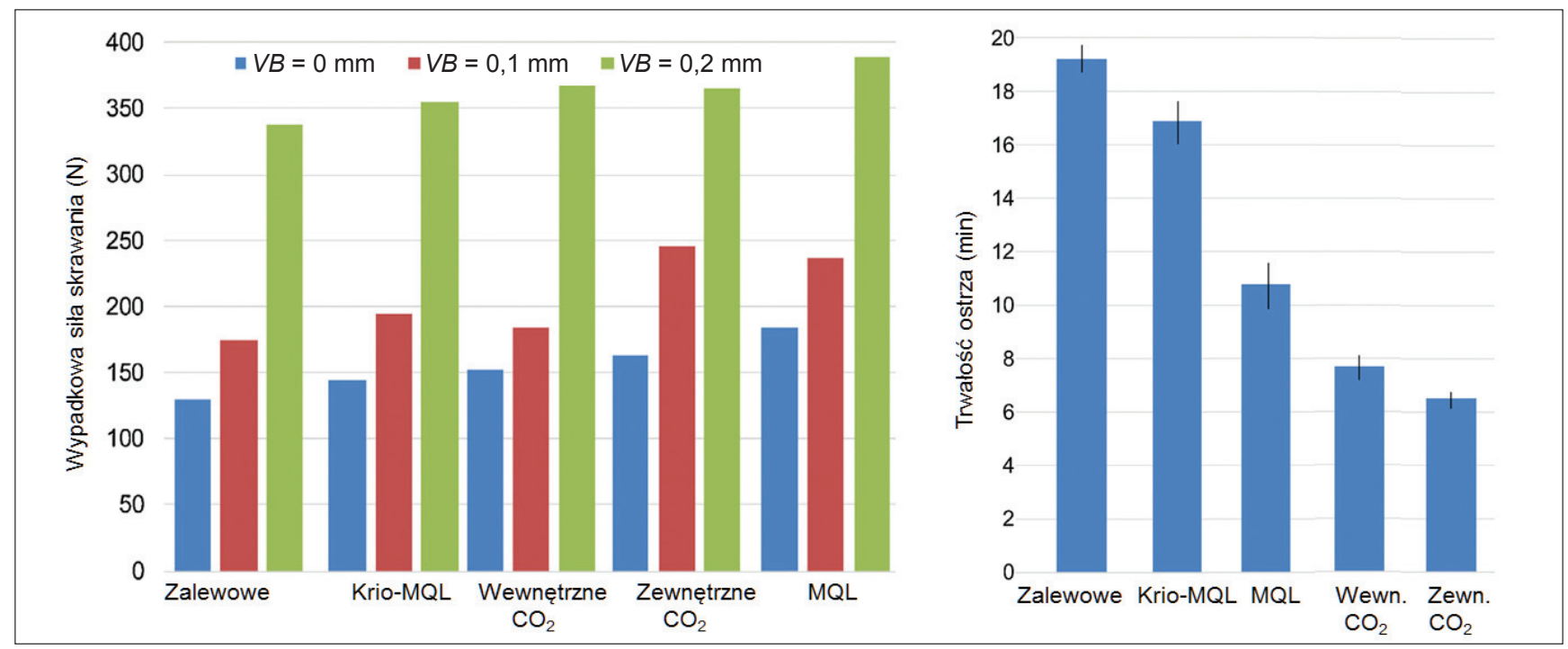

Fig. 15. Total cutting force evolution and tool life for the different cooling techniques at different wear stages [33] Rys. 15. Siły skrawania oraz trwałość ostrza w różnych technikach chłodzenia [33]
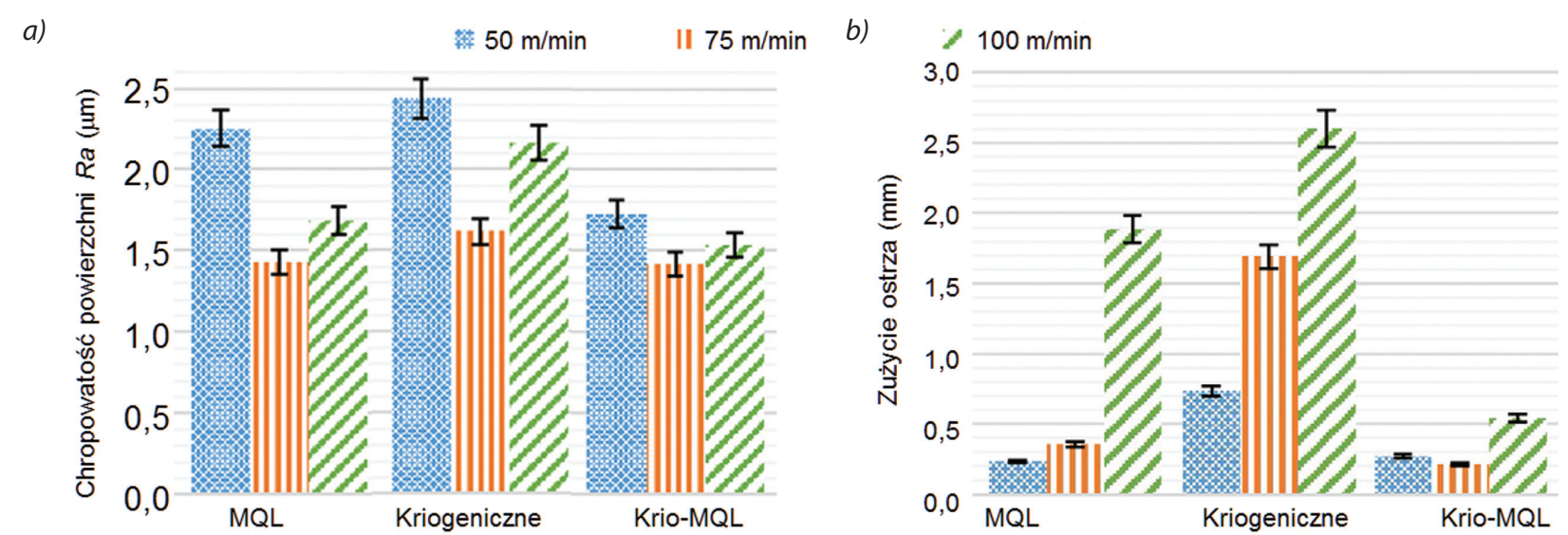

Fig. 16. The effect of cooling regimes and cutting speed on: $a$ ) surface roughness and $b$ ) tool wear [34]

Rys. 16. Wpływ sposobów chłodzenia i prędkości skrawania na: a) chropowatość powierzchni i b) zużycie ostrza [34] 
Porównywano smarowanie zewnętrzne MQL z $\mathrm{CO}_{2}$ jako chłodziwem wewnętrznym podczas frezowania Inconelu $718 \mathrm{z}$ innymi technikami chłodzenia [33]. Najdłuższy okres trwałości osiągnięto przy chłodzeniu zalewowym, ale techniki tej należy unikać z omówionych wcześniej względów. Chłodzenie kriogeniczne $\mathrm{CO}_{2}$ jak również samo smarowanie MQL nie są wystarczające do obróbki stopów żaroodpornych ze względu na niską trwałość ostrza. Do takich zastosowań najlepszym rozwiązaniem jest krio-MQL (rys. 15). Również w obróbce Inconelu 625 chłodzenie krio-MQL (MQL + $\mathrm{LN}_{2}$ ) okazało się lepsze od kriogenicznego lub samego MQL (rys. 16) [34].

Modelowanie matematyczne charakterystyk przepływu dysz $\mathrm{LN}_{2}$ i MQL wykazało, że strategia chłodzenia, która daje największy efekt chłodzenia, polega na wtryskiwaniu $\mathrm{LN}_{2}$ na powierzchnię przyłożenia i MQL na powierzchnię natarcia [35]. Interakcja między dwoma strumieniami wymusza pozostawanie znacznej ilości ciekłego azotu w szczelinie między powierzchnią przyłożenia a powierzchnią obrabianą. Badania obróbki Ti6Al4V potwierdziły wyższą wydajność tej strategii chłodzenia krio-MQL w zakresie zużycia narzędzia i jakości warstwy wierzchniej w porównaniu $\mathrm{z}$ chłodzeniem zalewowym, kriogenicznym i pod wysokim ciśnieniem (rys. 17) [32, 35].

Aby poprawić skuteczność smarowania krio-MQL - w którym MQL dostarczano z powierzchni natarcia, a $\mathrm{CO}_{2} \mathrm{z}$ powierzchni przyłożenia - zaproponowano połączenie minimalnej ilości dwutlenku węgla i oleju (CMQL) dostarczanych z powierzchni natarcia [36]. Chłodzenie CMQL zwiększyło trwałość narzędzia do $60 \%$ i $30 \%$ podczas toczenia odpowiednio: Ti6Al4V i Inconelu 718 oraz pozwoliło na uzyskanie lepszej
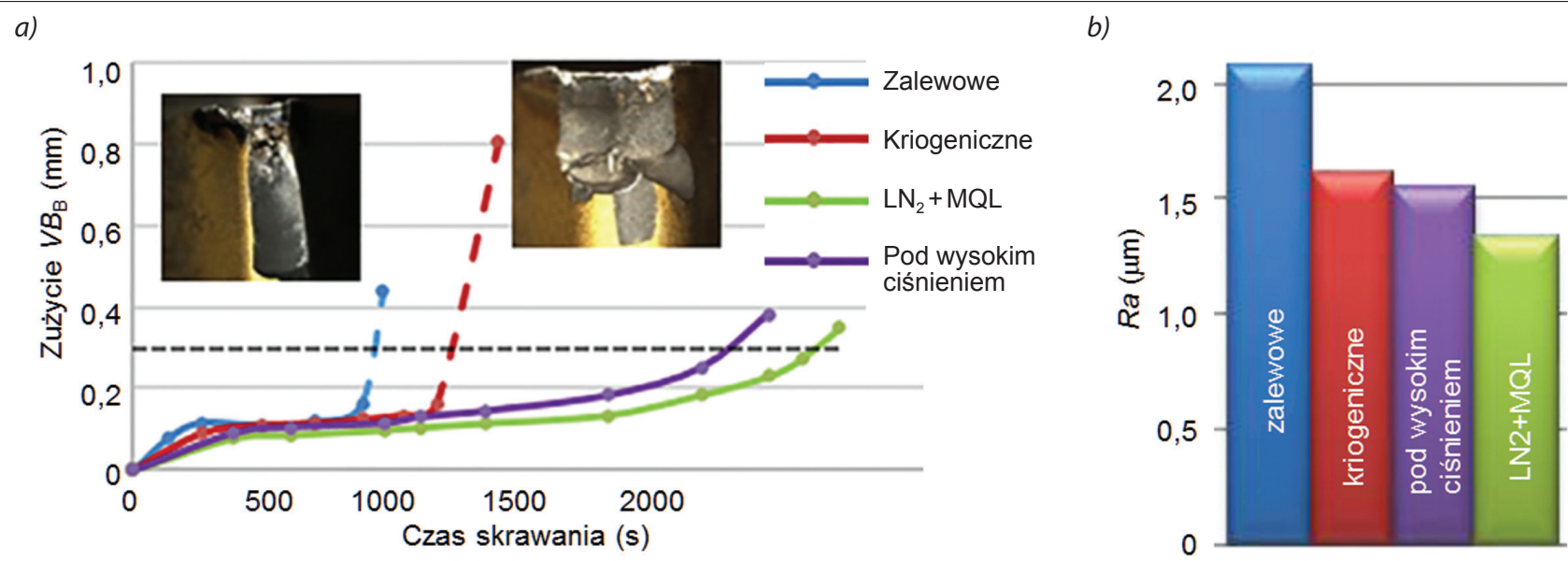

Fig. 17. Tool wear curve (a) and surface roughness (b) for the tested cooling methods [35]

Rys. 17. Przebiegi zużycia ostrza (a) i chropowatość powierzchni (b) w różnych metodach chłodzenia [35]

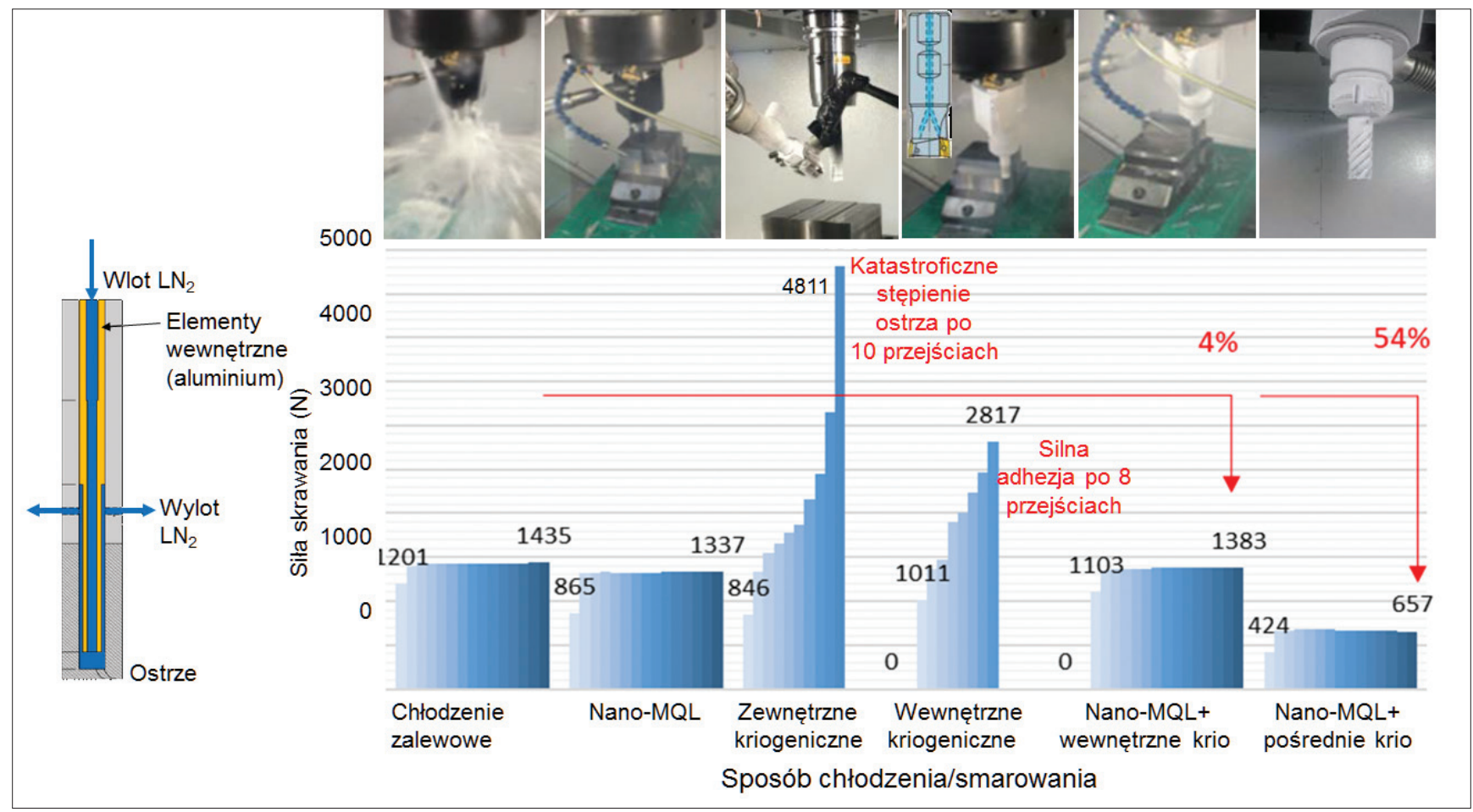

Fig. 18. Tool for indirect cryogenic cooling and cutting force with different lubrication strategies depending on the number of cutting passes [37] Rys. 18. Narzędzie do pośredniego chłodzenia kriogenicznego i siły skrawania w różnych strategiach smarowania w zależności od liczby przejść skrawania [37] 
jakości powierzchni w porównaniu z krio-MQL. CMQL zapewnia również największe ograniczenie długości styku narzędzia z wiórem, dzięki gładszej dolnej stronie wióra oraz wyższej wydajności usuwania ciepła $\mathrm{w}$ porównaniu z innymi metodami.

Chociaż chłodzenie ciekłym azotem zostało wdrożone do obróbki stopów tytanu, wpływ bardzo niskiej temperatury chłodziwa (do $-150^{\circ}$ ) na powierzchnię obrabianego przedmiotu powoduje jej utwardzenie, zwiększając w ten sposób siły skrawania. Rozwiązaniem może tu być zastosowanie pośredniego chłodzenia kriogenicznego.

Zaproponowano specjalnie zaprojektowany zestaw narzędzi, który umożliwia wewnętrzne doprowadzanie ciekłego azotu do narzędzia skrawającego i jego chłodzenie bez oddziaływania na przedmiot obrabiany [37]. Na rys. 18 przedstawiono narzędzie do pośredniego chłodzenia kriogenicznego oraz zestawienie wartości sił skrawania w różnych strategiach smarowania w zależności od liczby przejść. Nano-MQL, nano-MQL z wewnętrznym chłodzeniem kriogenicznym i nano-MQL z pośrednim chłodzeniem kriogenicznym generowały niższe siły skrawania $\mathrm{w}$ porównaniu $\mathrm{z}$ chłodzeniem zalewowym odpowiednio o: 7\%, 4\% i 54\%. Jednak przy zewnętrznym chłodzeniu kriogenicznym w 10. przejściu wystąpiło katastroficzne stępienie ostrza, a przy chłodzeniu kriogenicznym wewnętrznym stępienie narzędzia z powodu silnej adhezji wystąpiło w 8. przejściu. Stąd proponowane chłodzenie pośrednie wraz ze strategią smarowania nano-MQL stanowi doskonałe rozwiązanie problemu nadmiernego utwardzania przedmiotu obrabianego. Siła skrawania jest znacznie zmniejszona, a dzięki smarowaniu rowka wiórowego wióry są łatwo usuwane, co dodatkowo obniża siłę skrawania.

Narzędzia $\mathrm{z}$ diamentu polikrystalicznego (PCD) nie są powszechnie stosowane do szybkościowej obróbki stopów tytanu ze względu na ich podatność na termiczne zużycie chemiczne. Stwierdzono jednak, że w wyniku zastosowania chłodzenia kriogenicznego ciekłym azotem zjawiska tribologiczne zmieniaja się wystarczająco, aby umożliwić zadowalającą wydajność obróbki Ti6Al4V przy bardzo niewielkim zużyciu ostrza $(V B<10 \mu \mathrm{m}$ po $65 \mathrm{~min}$ obróbki przy $v_{c}=240 \mathrm{~m} / \mathrm{min}$ ) i niskiej chropowatości powierzchni $(R a=40 \mathrm{~nm})$ [37]. Co ciekawe, chłodzenie zalewowe nie prowadziło do zmniejszenia chropowatości powierzchni. Chłodzenie krio-MQL ( $\mathrm{LN}_{2}$ i MQL na bazie oleju) zredukowało siły skrawania w porównaniu zarówno z chłodzeniem zalewowym, jak i kriogenicznym. We wszystkich warunkach chłodzenia siły skrawania były mniejsze niż $15 \mathrm{~N}$, co sugeruje, że kriogeniczna precyzyjna obróbka narzędziami z PCD może być alternatywą dla szlifowania, nawet w przypadku elementów smukłych i cienkościennych.

\section{Chłodzenie pod wysokim ciśnieniem}

Spośród dostępnych technik chłodzenia/smarowania obróbka wspomagana strumieniem pod wysokim ciśnieniem umożliwia zwiększenie produktywności oraz obniżenie temperatury w strefie skrawania,
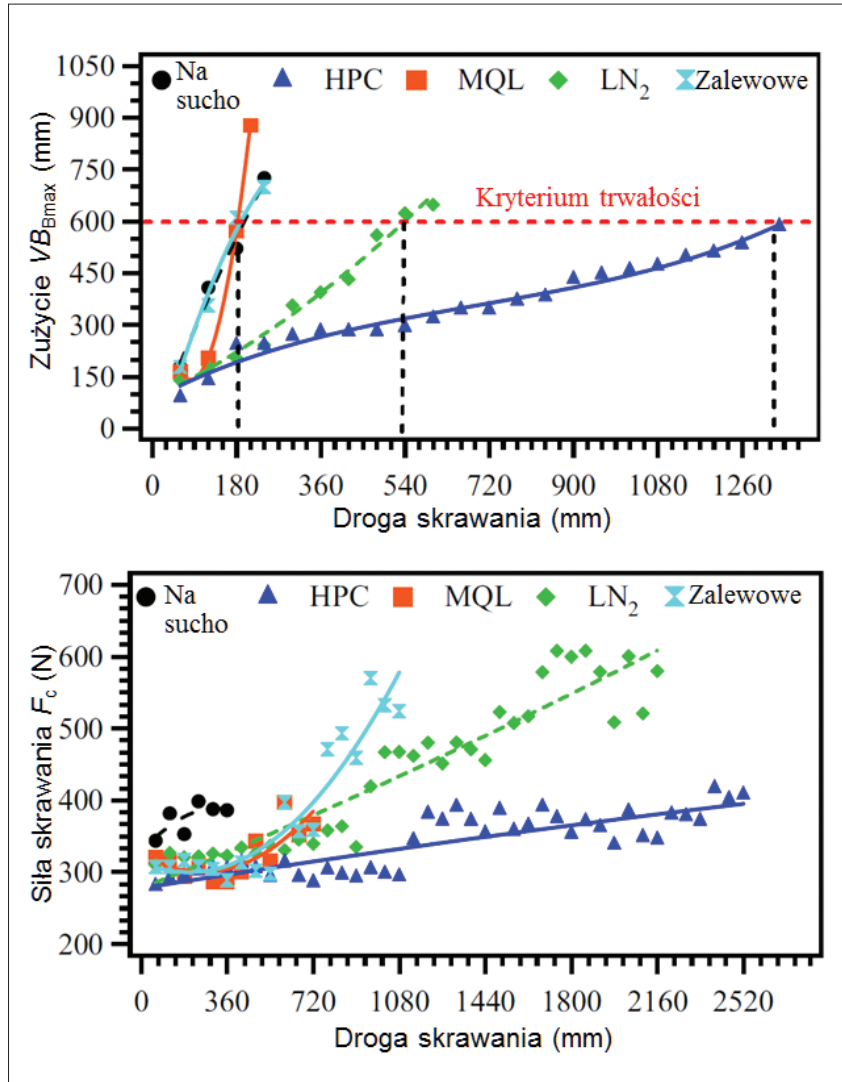

Fig. 19. Tool wear rate and surface roughness of the parts machined under various machining conditions [41]

Rys. 19. Zużycie ostrza i siły skrawania w różnych warunkach chłodzenia [41]

zapewnia doskonałe łamanie wiórów i redukcję kosztów związanych z płynami obróbkowymi [39].

Stwierdzono, że dostarczanie chłodziwa pod wysokim ciśnieniem (high-pressure cooling - HPC) znacznie zmniejsza współczynnik tarcia i temperaturę podczas obróbki Ti-5553, co w rezultacie zmniejsza siły skrawania i zużycie ostrza (rys. 19). Doprowadzenie chłodziwa pod wysokim ciśnieniem zapewnia więc największą trwałość ostrza, a na drugim miejscu jest chłodzenie kriogeniczne. Smarowanie minimalne (MQL) jest w tym przypadku nieefektywne $[40,41]$.

Próba zastosowania HPC w obróbce Inconelu 625 narzędziami ceramicznymi na bazie SiAlON pokazała, że nie zwiększa ono ani nie skraca trwałości ostrza $\mathrm{w}$ porównaniu $\mathrm{z}$ chłodzeniem konwencjonalnym. Zużycie narzędzia charakteryzowało się starciem powierzchni przyłożenia i wykruszaniem krawędzi. Zużycie skoncentrowane (karb) nie było znaczące. Jednak chłodzenie wysokociśnieniowe przyczyniło się do doskonałego łamania wiórów [42]. Średnica dyszy i ciśnienie strumienia to najważniejsze czynniki wpływające na temperaturę narzędzia skrawającego. Znaczne zmniejszenie wielkości wiórów można osiągnąć przez zwiększenie ciśnienia strumienia [39]. Przy zastosowaniu HPC do toczenia zgrubnego Inconelu 718 okazało się, że wprawdzie zużycie skoncentrowane (karb) $V B_{C}$ jest większe niż przy chłodzeniu konwencjonalnym, ale zużycie powierzchni przyłożenia $V B_{\mathrm{B}}$ jest znacznie mniejsze, pozwalając na osiągnięcie około dwukrotnie dłuższego okresu trwałości ostrza (rys. 20) [43]. 

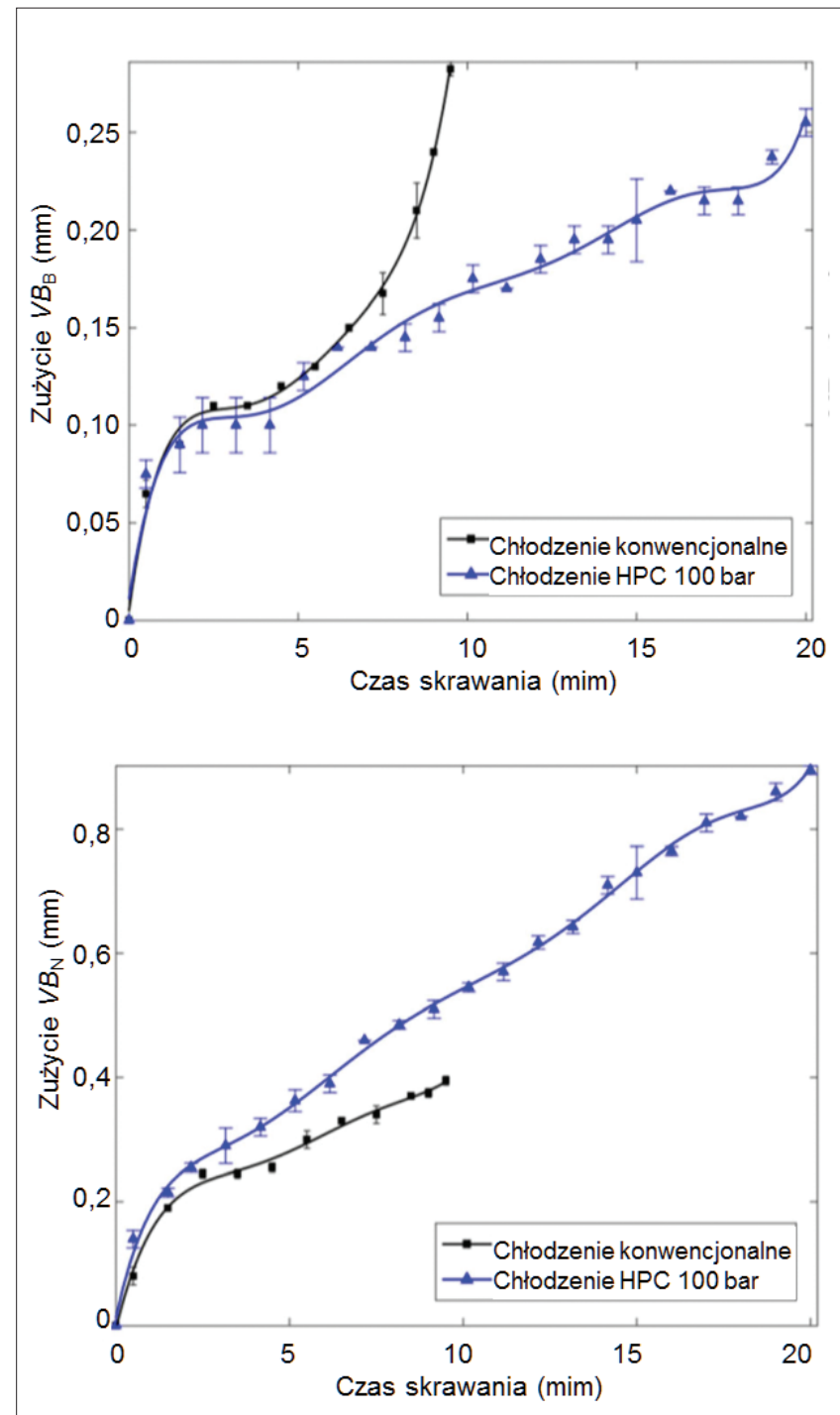

Fig. 20. Tool wear for Inconel 718 rough turning with conventional cooling and $\mathrm{HPC}, v_{\mathrm{c}}=35 \mathrm{~m} / \mathrm{min}$ [43]

Rys. 20. Zużycie ostrza przy toczeniu zgrubnym Inconelu 718 z chłodzeniem konwencjonalnym i HPC, $v_{c}=35 \mathrm{~m} / \mathrm{min}$ [43]

\section{Wnioski}

Wysoko wydajne i przyjazne dla środowiska metody chłodzenia są stosowane do obróbki materiałów lotniczych od kilku lat. W ostatnim czasie nastąpiło jednak znaczne przyspieszenie rozwoju tych technik, a także prób ich łączenia, co znacząco poprawia ich skuteczność dzięki efektowi synergii. Minimalne smarowanie (MQL) połączono z chłodzeniem kriogenicznym (krio-MQL) i wzbogacono nanododatkami.

Mimo imponujących osiągnięć nadal nie można uznać opisanych technik za opanowane i łatwe do zastosowania. W każdym przypadku konieczny jest staranny dobór parametrów procesu. Należy się jednak spodziewać dalszego szybkiego rozwoju metod obróbki materiałów lotniczych, warto więc śledzić doniesienia literaturowe.

Pełna, angielska wersja artykułu znajduje się: Jemielniak K. "Review of new developments in machining of aerospace materials". Journal of Machine Engineering. 21, 1 (2021): 22-55, doi.org/10.36897/jme/132905.

\section{LITERATURA}

[1] M'Saoubi R., Axinte R., Soo S.L., Nobel C., Attia H., Kappmeyer G., Engin S., Sim W.M. "High performance cutting of advanced aerospace alloys and composite materials". CIRP Annals - Manufacturing Technology. 64, 2 (2015): 557-580, https://doi.org/10.1016/j.cirp.2015.05.002.

[2] Deshpande Y.V., Andhare A.B., Padole P.M. "How cryogenic techniques help in machining of nickel alloys? A review". Machining Science and Technology. 22/4 (2018): 543-584, https://doi.org/10.1080/10910344.2017.1382512.

[3] Osman K.A., Ünver H.Ö., Şeker U. "Application of minimum quantity lubrication techniques in machining process of titanium alloy for sustainability: A review". Int J Adv Manuf Technol. 100 (2019): 2311-2332, https://doi. org/10.1007/s00170-018-2813-0.

[4] Pervaiz S., Anwar S., Qureshi I., Ahmed N. "Recent advances in the machining of titanium alloys using minimum quantity lubrication (MQL) based techniques". Int. J. Precis. Eng. Manuf.-Green Technol. 6 (2019): 133-145, https:// doi.org/10.1007/s40684-019-00033-4.

[5] Said Z., Gupta M., Hegab H., Arora N., Khan A.M., Jamil M., Bellos E. "A comprehensive review on minimum quantity lubrication (MQL) in machining processes using nano-cutting fluids". Int J Adv Manuf Technol. 105 (2019): 2057-2086, https://doi.org/10.1007/s00170-019-04382-x.

[6] Wei Fan, Wei Ji, Lihui Wang, Lianyu Zheng, Yahui Wang. "A review on cutting tool technology in machining of Ni-based superalloys". Int J Adv Manuf Technol. 110 (2020): 2863-2879, https://doi.org/10.1007/s00170020-06052-9.

[7] Ross K.N.S., Manimaran G. "Effect of cryogenic coolant on machinability of difficult-to-machine $\mathrm{Ni}-\mathrm{Cr}$ alloy using PVD-TiAlN coated WC tool". Journal of the Brazilian Society of Mechanical Sciences and Engineering. 41 (2019): 44, https://doi.org/10.1007/s40430-018-1552-3.

[8] Pušavec F., Grguraš D., Koch M., Krajnik P. "Cooling capability of liquid nitrogen and carbon dioxide in cryogenic milling". CIRP Annals - Manufacturing Technology. 68 (2019): 73-76, https://doi.org/10.1016/j.cirp.2019.03.016.

[9] Jamil M., Khan A.M., Gupta M.K., Mia M., He N., Li L., Sivalingam V. "Influence of $\mathrm{CO}_{2}$-snow and subzero MQL on thermal aspects in the machining of Ti-6Al-4V". Applied Thermal Engineering. 177 (2020): 115480, https://doi.org/10.1016/j.applthermaleng.2020.115480.

[10] Damir A., Sadek A., Attia H. "Characterization of Machinability and Environmental Impact of Cryogenic Turning of Ti-6Al-4V". Procedia CIRP. 69 (2018): 893-898, https:// doi.org/10.1016/j.procir.2017.11.070.

[11] Jawahir I.S., Attia H., Biermann D., Duflou J., Klocke F., Meyer D., Newman S.T., Pusavec F., Putz M., Rech J., Schulze V., Umbrello D. "Cryogenic manufacturing processes". CIRP Annals - Manufacturing Technology. 65 (2016): 713-736, https://doi.org/10.1016/j.cirp.2016.06.007.

[12] Shah P., Khanna N., Chetan A. "Comprehensive machining analysis to establish cryogenic $\mathrm{LN}_{2}$ and $\mathrm{LCO}_{2}$ as sustainable cooling and lubrication techniques". Tribology International. 148 (2020): 106314, https://doi.org/10.1016/j.triboint.2020.106314.

[13] Chetan A., Khanna N., Pruncu C.I., Singla A.K., Gupta M.K. "Tool wear progression and its effects on energy consumption and surface roughness in cryogenic assisted turning of Ti-6Al-4V". Int J Adv Manuf Technol. 111 (2020): 1319-1331, https://doi.org/10.1007/s00170-020-06140-w.

[14] Chaabani S., Arrazola P.J., Ayed Y., Madariaga A., Tidu A., Germain G. "Comparison between cryogenic coolants effect on tool wear and surface integrity in finishing turning of Inconel 718". Journal of Materials Processing Tech. 285 (2020): 116780, https://doi.org/10.1016/j.jmatprotec.2020.116780.

[15] Sartori S., Pezzato L., Dabalà M., Enrici T.M., Mertens A., Ghiotti A., Bruschi S. "Surface Integrity Analysis of Ti6Al4V 
After Semi-finishing Turning Under Different Low-Temperature Cooling Strategies". J. of Materi Eng and Perform. 27 (2018): 4810-4818, https://doi.org/10.1007/s11665018-3598-x.

[16] Sartori S., Taccin M., Pavese G., Ghiotti A., Bruschi S. "Wear mechanisms of uncoated and coated carbide tools when machining Ti6Al4V using LN2 and cooled N2". Int J Adv Manuf Technol. 95 (2018): 1255-1264, https://doi. org/10.1007/s00170-017-1289-7.

[17] Kirsch B., Basten S., Hasse H., Aurich J.C. "Sub-zero cooling: A novel strategy for high performance cutting". CIRP Annals - Manufacturing Technology. 67 (2018): 95-98, https://doi.org/10.1016/j.cirp.2018.04.060.

[18] Kumar D., Gururaja S. "Machining damage and surface integrity evaluation during milling of UD-CFRP laminates: Dry vs. cryogenic". Composite Structures. 247 (2020): 112504, https://doi.org/10.1016/j.compstruct.2020.112504.

[19] Okafor A.C., Nwoguh T.0. "Comparative evaluation of soybean oil-based MQL flow rates and emulsion flood cooling strategy in high-speed face milling of Inconel 718". Int Adv Manuf Technol. 107 (2020): 3779-3793, https://doi. org/10.1007/s00170-020-05248-3.

[20] Lan Dong, Changhe Li, Xiufang Bai, Mingge Zhai, Qiang Qi, Xiaojie Lv, Lifang Li. "Analysis of the cooling performance of Ti-6Al-4V in minimum quantity lubricant milling with different nanoparticles". Int J Adv Manuf Technol. 103 (2019): 2197-2206, https://doi.org/10.1007/s00170019-03466-y.

[21] Hegab H., Umer U., Soliman M., Kishawy H.A. "Effects of nano-cutting fluids on tool performance and chip morphology during machining Inconel 718". Int J Adv Manuf Technol. 96 (2018): 3449-3458, https://doi.org/10.1007/s00170018-1825-0.

[22] Marques A., Suarez M.P., Sales W.F., Machado Á.R. "Turning of Inconel 718 with whisker-reinforced ceramic tools applying vegetable-based cutting fluid mixed with solid lubricants by MQL". Journal of Materials Processing Tech. 266 (2019): 530-543, https://doi.org/10.1016/j.jmatprotec.2018.11.032.

[23] Sivalingam V., Zan Z., Sun J., Selvam B., Gupta M.K., Jamil M., Mia M. "Wear behaviour of whisker-reinforced ceramic tools in the turning of Inconel 718 assisted by an atomized spray of solid lubricants". Tribology International. 148 (2020): 106235, https://doi.org/10.1016/j.triboint.2020.106235

[24] Sartori S., Ghiotti A., Bruschi S. "Solid Lubricant-assisted Minimum Quantity Lubrication and Cooling strategies to improve Ti6Al4V machinability in finishing turning". Tribology International. 118 (2018): 287-294, https://doi. org/10.1016/j.triboint.2017.10.010.

[25] Li M., Yu T., Zhang R., Li H., Wang W. "MQL milling of TC4 alloy by dispersing graphene into vegetable oil-based cutting fluid". Int J Adv Manuf Technol. 99 (2018): 1735-1753, https://doi.org/10.1007/s00170-018-2576-7.

[26] Gong L., Bertolini R., Ghiotti A., He N., Brusch S. "Sustainable turning of Inconel 718 nickel alloy using MQL strategy based on graphene nanofluids". Int J Adv Manuf Technol. 108 (2020): 3159-3174, https://doi.org/10.1007/ s00170-020-05626-x.

[27] Bertolini R., Gong L., Ghiotti A., Bruschi S. “Graphene Nanoplatelets-Assisted Minimum Quantity Lubrication in Turning to Enhance Inconel 718 Surface Integrity". Procedia CIRP. 87 (2020): 71-76, https://doi.org/10.1016/j. procir.2020.02.021.

[28] Shuang Yi, John Mo, Songlin Ding. "Experimental investigation on the performance and mechanism of graphene oxide nanofluids in turning Ti-6Al-4V". Journal of Manufacturing Processes. 43 (2019): 164-174, https://doi.org/10.1016/j. jmapro.2019.05.005.

[29] Guangxian Li, Shuang Yi, Nan Li, Wencheng Pan, Cuie Wen, Songlin Ding. "Quantitative analysis of cooling and lubri- cating effects of graphene oxide nanofluids in machining titanium alloy Ti6Al4V". Journal of Materials Processing Tech. 271 (2019): 584-598, https://doi.org/10.1016/j. jmatprotec.2019.04.035.

[30] Shokrani A., Betts J. "A new hybrid minimum quantity lubrication system for machining difficult-to-cut materials". CIRP Annals - Manufacturing Technology. 69 (2020): 73-76, https://doi.org/10.1016/j.cirp.2020.04.027.

[31] Bartolomeis A.D., Shokrani A. "Electrohydrodynamic Atomization for Minimum Quantity Lubrication (EHDA-MQL) in End Milling Ti6Al4V Titanium Alloy". J. Manuf. Mater. Process. 4 (2020): 70, https://doi.org/10.3390/ jmmp4030070.

[32] Shokrani A., Al-Samarrai I., Newman S.T. "Hybrid cryogenic MQL for improving tool life in machining of Ti-6Al-4V titanium alloy". Journal of Manufacturing Processes. 43 (2019): 229-243, https://doi.org/10.1016/j.jmapro.2019.05.006.

[33] Pereira O., Celaya A., Urbikaín G., Rodríguez A., Fernández-Valdivielso A., Lacalle L.N.L. " $\mathrm{CO}_{2}$ cryogenic milling of Inconel 718: cutting forces and tool wear". Journal of Materials Research and Technology. 9 (2020): 8459-8468, https://doi.org/10.1016/j.jmrt.2020.05.118.

[34] Yildirim C.V., Kivak T., Sarikaya M., Sirin S. "Evaluation of tool wear, surface roughness/topography and chip morphology when machining of Ni-based alloy 625 under MQL, cryogenic cooling and CryoMQL". Journal of Materials Research and Technology. 9/2 (2020): 2079-2092, https://doi.org/10.1016/j.jmrt.2019.12.069.

[35] Damir A., Shi B., Attia M.H. "Flow characteristics of optimized hybrid cryogenic-minimum quantity lubrication cooling in machining of aerospace materials". CIRP Annals Manufacturing Technology. 68 (2019): 77-80, https://doi. org/10.1016/j.cirp.2019.04.047.

[36] Bagherzadeh A., Budak E. "Investigation of machinability in turning of difficult-to-cut materials using a new cryogenic cooling approach". Tribology International. 119 (2018): 510-520, https://doi.org/10.1016/j.triboint.2017.11.033.

[37] Suhaimi Mohd Azlan, Yang Gi-Dong, Park Kyung-Hee, Hisam Mohd Juzaili, Sharif Safian, Kim Dong-Won. "Effect of Cryogenic Machining for Titanium Alloy Based on Indirect, Internal and External Spray System". Procedia Manufacturing. 17 (2018): 158-165, https://doi.org/10.1016/j. promfg.2018.10.031.

[38] Schoop J., Sales W.F., Jawahir I.S. "High speed cryogenic finish machining of Ti-6Al4V with polycrystalline diamond tools". Journal of Materials Processing Tech. 250 (2017): 1-8, https://doi.org/10.1016/j.jmatprotec.2017.07.002.

[39] Cica D., Kramar D. "Multi-objective optimization of high-pressure jet-assisted turning of Inconel 718". Int J Adv Manuf Technol. 105 (2019): 4731-4745, https://doi. org/10.1007/s00170-019-04513-4.

[40] Kaynaka Y., Gharibi A., Yilmaz U., Köklü U., Aslantas K. "A comparison of flood cooling, minimum quantity lubrication and high pressure coolant on machining and surface integrity of titanium Ti-5553 alloy". Journal of Manufacturing Processes. 34 (2018): 503-512, https://doi. org/10.1016/j.jmapro.2018.06.003.

[41] Tascioglu E., Gharibi A., Kaynak Y. "High speed machining of near-beta titanium Ti-5553 alloy under various cooling and lubrication conditions". Int J Adv Manuf Technol. 102 (2019): 4257-4271, https://doi.org/10.1007/s00170019-03291-3.

[42] Sørby K., Vagnorius Z. "High-pressure cooling in turning of Inconel 625 with ceramic cutting tools". Procedia CIRP. 77 (2018): 74-77, https://doi.org/10.1016/j.procir.2018.08.221.

[43] Khochtali H., Ayed Y., Zemzemi F., Bensalem W. "Tool wear characteristics in rough turning of Inconel 718 with coated carbide tool under conventional and high-pressure coolant supplies". Int J Adv Manuf Technol. 114 (2021): 2371-2386, https://doi.org/10.1007/s00170-021-07002-9. 